Brit. J. vener. Dis. (1962), 38, 218.

\title{
STRAIN SENSITIVITY OF TRICHOMONAS VAGINALIS
}

\section{TO METRONIDAZOLE*}

\author{
BY \\ S. SQUIRES AND J. A. MCFADZEAN \\ The Research Laboratories, May and Baker Ltd., Dagenham, Essex
}

A previous publication (Kane, McFadzean, Squires, King, and Nicol, 1961) gave the possible reasons for the failure of metronidazole to eradicate Trichomonas vaginalis from a small percentage of treated patients. Evidence was obtained (Kane, McFadzean, and Squires, 1961) that a number of failures could be due to defective absorption of the compound. The results of investigating another possibility, namely, resistance of the parasite to the compound, are now presented.

\section{Methods}

Patients who apparently failed to respond to the standard course of the drug $(200 \mathrm{mg}$. three times daily for 7 days) were swabbed and a culture was taken into a liver infusion broth of the following composition:

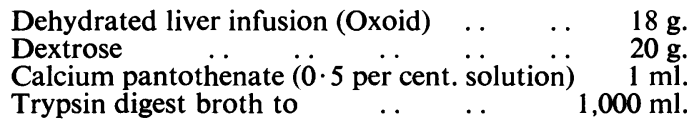

The medium was adjusted to $\mathrm{pH} 6$ and sterilized at a steam pressure of $5 \mathrm{lb}$. per sq. in. for 15 minutes. Before use, 10 per cent. $v / v$ inactivated sterile horse serum was added and penicillin, streptomycin, and Mycostatin were also included to eliminate bacterial and mycotic contamination.

Cultures were collected at a number of different centres. On arrival at the laboratory, they were examined microscopically to determine viability, and then incubated at $37^{\circ} \mathrm{C}$. for $24 \mathrm{hrs}$ and re-examined. All viable cultures at this time were subcultured and then examined for sensitivity to metronidazole by a serial dilution method, using the medium described above. After 24 hrs' incubation, the deposit in each tube was examined microscopically for evidence of motile trichomonads, and the highest dilution in which no motile organisms were seen was recorded as the minimal inhibitory concentration.

\footnotetext{
* Received for publication June, 251962
}

\section{Results}

The results are shown in the Table. Of 42 cultures submitted for sensitivity determination, sixteen were not viable on arrival. Of the other 26 strains, seven were inhibited by $0.25 \mu \mathrm{g} . / \mathrm{ml}$., thirteen by $0.5 \mu \mathrm{g} . / \mathrm{ml}$., and six by $1 \mu \mathrm{g} . / \mathrm{ml}$. No strain grew at a concentration above $1 \mu \mathrm{g} . / \mathrm{ml}$. These sensitivities were within the range obtained against strains maintained before the introduction of metronidazole.

TABLE

RANGE OF SENSITIVITY TO METRONIDAZOLE OF STRAINS OF T. VAGINAI.IS ISOLATED FROM PRIMARY FAILURES

\begin{tabular}{|c|c|c|c|c|c|}
\hline \multirow{2}{*}{$\begin{array}{l}\text { No. of } \\
\text { Cultures } \\
\text { Taken }\end{array}$} & \multirow{2}{*}{$\begin{array}{l}\text { No. of } \\
\text { Cultures } \\
\text { Viable }\end{array}$} & \multicolumn{3}{|c|}{$\begin{array}{l}\text { Sensitivity to } \\
\text { Metronidazole }(\mu \mathrm{g} .)\end{array}$} & \multirow{2}{*}{$\begin{array}{l}\text { Sensitivity of } \\
\text { Stock Strain }\end{array}$} \\
\hline & & $0 \cdot 25$ & 0.05 & 1 & \\
\hline 42 & 26 & 7 & 13 & 6 & $0.25-1 \mu \mathrm{g}$. \\
\hline
\end{tabular}

\section{Discussion}

Of the various factors involved in the failure of patients to respond to the therapeutic action of metronidazole, the possibility of the occurrence of resistant strains of the protozoon was of prime importance. From the limited in vitro studies reported here, it would seem that no strain of $T$. vaginalis resistant to metronidazole has so far appeared, and resistance has not therefore been the causative factor in the failure to respond to the drug. Jennison, Stenton, and Watt (1961) have reported failure to induce resistance in $T$. vaginalis to metronidazole in vitro and attempts made in these laboratories have also failed.

\section{Summary}

Of 42 cultures of $T$. vaginalis taken from patients failing to respond to metronidazole and examined 218 
for sensitivity to the drug, 26 were viable on arrival at the laboratory. The sensitivity to metronidazole of these strains was within the range of $0 \cdot 25-1 \mu \mathrm{g} . / \mathrm{ml}$., the same sensitivity as stock strains isolated before the introduction of the drug.

Thanks are due to Drs. P. Rodin, C. S. Nicol, and M. Scott Gray, and to a number of other clinicians for kindly supplying the cultures.

\section{ADDENDUM}

Since this work was carried out we have seen a report (Robinson, 1962) that a strain of Trichomonas vaginalis, resistant to metronidazole, has been isolated. Unfortunately this strain is not available for investigation.

\section{REFERENCES}

Jennison, R. F., Stenton, P., and Watt, L. (1961). J. clin. Path., 14, 431.

Kane, P. O., McFadzean, J. A., Squires, S. (1961). Brit. J. vener. Dis., 37, 276.

,,--- King, A. J., and Nicol, C. S. (1961). Brit. J. vener. Dis., 37, 273 .

Robinson, S. C. (1962). Canad. med. Ass. J., 86, 665.

Sensibilité des souches de $T$. vaginalis au métronidazole RÉSUMÉ

Sur 42 souches de $T$. vaginalis prélevées sur des malades qui ne répondaient pas au métronidazole et dont la sensibilité au métronidazole fut examinée, 26 étaient encore en vie en arrivant au laboratoire. La sensibilité de ces souches fut de 0,25 à $1 \mu \mathrm{g}$. $/ \mathrm{ml}$., la même que celle des souches isolées avant l'introduction de ce médicament. 